\title{
PENINGKATAN KOMPETENSI GURU DALAM MENYUSUN SILABUS KURIKULUM 2013 MELALUI BINTEK PADA GURU PENDIDIKAN AGAMA HINDU DI GUGUS I KECAMATAN KINTAMANI KABUPATEN BANGLI TAHUN 2018
}

\author{
Oleh : \\ I Wayan Miarta \\ Kantor Kementerian Agama Kabupaten Bangli \\ miarta1961@gmail.com
}

Diterima 11 Oktober 2018, direvisi 6 Pebruari 2019, diterbitkan 29 Maret 2019

\begin{abstract}
The aims of this study is to improve teacher potential through Bimtek to compile the 2013 Curriculum Syllabus in Cluster 1 of Kintamani District, and Bangli Regency. This study was Regional School Action Research (PTSW) using two cycle designs and each cycle consists of four stages, namely: planning, action, observation, and reflection. In collecting the data, this study used measurement techniques, in the form of tests to obtain quantitative data. The observation sheet is used to obtain qualitative data. The data was analyzed by using descriptive analysis. There are 11 Hinduism Teachers, in Cluster 1 with less moderate and capable criteria. The teachers are ability to compile the syllabus as a classroom learning plan. The results showed that the quality of Hindu teachers in Cluster I gets enough title and the teacher who gets a good predicate is $45 \%$ so that the increase is $17 \%$ from enough to good. Furthermore, while the first cycle received a very good predicate as much as $18 \%$ in cycle 2 to $55 \%$ so that it experienced a $37 \%$ increase in the number of syllabus compilation from cycle I to cycle II. However, based on the result of this study was effective to achieve the target.
\end{abstract}

Keywords : Improvement of Teacher Competence in preparing the K13 Syllabus through Bimtek in Kintamani Cluster 1.

\section{PENDAHULUAN}

Sejak diberlakukannya kurikulum 13 (K13), secara serentak tahun 2018 maka semua guru wajib memiliki kemampuan atau kompetensi untuk mempersiapkan diri dalam membuat perencanaan, pembelajaran. Persiapan yang perlu direncanakan oleh guru harus berdasarkan perundang-undangan yang berlaku. Perkembangan dan perubahan peraturan di bidang pendidikan sangat pesat terutama dalam K13. Ada lima (5) peraturan menteri yang mengalami perubahan sebagai pedoman pelaksaan tugas bagi guru dalam pembelajaran. Peraturan menteri tersebut antara lain : 1. Permen dikbud no: 20 tahun
2016 isinya: tentang standar kelulusan , 2 . Permen dikbud no: 21 tahun 2016 isinya : tentang standar isi, 3. Permen dikbud no: 22 tahun 2016, isinya : tentang standar proses, 4. Permen dikbud no : 23 tahun 2016, isinya: standar penilaian dan 5. Permen dikbud no: 24 tahun 2016 isinya: standar KI dan KD mata pelajaran (mapel).

Begitu banyaknya peraturan yang berubah menyebabkan guru dituntut memahami peraturan-peraturan dimaksud. Salah satu cara untuk menyamakan persepsi dalam memahami peraturan melalui bimbingan teknis. Berdasarkan hasil supervisi pengawas dengan wilayah binaan 10 gugus dengan 
jumlah guru Agama Hindu107 .maka sangat sulit bagi guru untuk mengimplementasikan peraturan dan perubahan K13 dalam membuat perangkat pembelajaran dalam bentuk silabus. Pembuatan silabus guru harus memahami dibidang peraturan, terutama permen dikbud nomor 22 tahun 2016 isinya : standar proses. Dari jumlah 107 guru Agama Hindu yang perlu diberi pembinaan adalah gugus I Kintamani dengan jumlah guru 11 Guru pada saat KKG di SDN 1 Batur sangat sulit membuat silabus karena mereka belum memiliki kemampuan pengetahuan dalam menuangkan KI dan KD ke dalam bentuk silabus dengan kata kerja operasional aksonominya ke tiga ranah dari ranah sikap, pengetahuan dan keterampilan masingmasing memiliki aksonominya. Karena dalam pertemuan KKG hanya gugus I belum mampu untuk membuat silabus maka gugus tersebut yang menjadi sasaran untuk pelaksanaan bimbingan teknis pembuatan silabus K13.

Berdasarkan atas hasil pemantauan pengawas pada saat pelaksanaan KKG Kec. Kintamani dapat diidentifikasikan permasalahan sebagai berikut :

1. Rendahnya pemahaman guru terhadap permen dikbud perubahan K13.

2. Kebanyakan guru belum pernah mengikuti bintek.

3. Rendahnya kemampuan guru dalam memahami kata kunci KD yang dituangkan dalam indikator pencapaian kompetensi dengan penggunaan KKO ketiga ranah.

4. Rendahnya kemampuan guru dalam membuat silabus K13.

5. Rendahnya kemampuan guru dalam membuat RPP K13.

6. Rendahnya kemampuan guru dalam mengimplementasikan K13 dalam proses pembelajaran.

Begitu banyaknya permasalahan yang dihadapi guru namun yang paling mendasar menjadi pokok permasalahan untuk diteliti adalah rendahnya kemampuan/kompetensi guru dalam menyusun Silabus Kurikulum
2013 melalui Bimtek di Gugus 1 Kecamatan Kintamani kabupaten bangli. Permasalahan dapat dirumuskan "Apakah melalui Bimtek dapat meningkatkan kemampuan guru menyusun silabus Kurikulum 2013 bagi Guru Agama Hindu tingkat SD di Gugus 1 Kecamatan Kabupaten Bangli ?"

Tujuan kegiatan ini untuk meningkatkan kompetensi guru dalam membuat silabus K.13 Gugus I Kintamani. Meningkatkan peran gugus dan peningkatan kualitas guru sebagai tempat pengembangan dan pelatihan bagi guru Agama Hindu di Gugus I Kintamani.

Yang dimaksud kompetensi guru adalah suatu tugas yang memadai atau pemilikan pengetahuan, keterampilan dan kemampuan yang dituntut oleh jabatan seseorang (Roestiah,1992:4) yang dimaksud dengan guru adalah : semua orang yang pernah memberikan suatu ilmu atau kepandaian tertentu kepada seseorang atau sekelompok orang (Poerwanto, 1989:169).

Berdasarkan kedua pengertian diatas maka dapat dipahami bahwa yang dimaksud kompetensi guru adalah kemampuan atau kekuasaan seseorang yang berperan sebagai pemberi ilmu pengetahuan atau kepandaian tertentu kepada anak didik atau sekelompok orang anak didik mampu dan menguasai ilmu pengetahuan tertentu.

Pengetahuan, keterampilan dan kecakapan manusia yang dikembangkan melalui belajar. Banyak cara yang dapat dilakukan untuk memperoleh ketiga aspek tersebut seperti belajar didalam sekolah, luar sekolah, tempat bekerja, sewaktu bekerja, melalui pengalaman, dan melalui bimbingan teknis adalah pertemuan ilmiah dalam bidang sejenis pendidikan untuk menghasilkan karya nyata (Bedudu,1988:403).

Dalam banyak bidang pelatihan bimbingan teknis tidak dapat diperlihatkan hasil yang obyektif. Pelatihan bimbingan teknis umumnya mempunyai masalah mengenai prestasi pembimbing/pelatih, penatar dalam mengajar, masalah evaluasi dan validasi selama proses kelangsungannya. Jika 
bimbingan telah diajarkan dengan baik pelatih telah melakukan pembelajaran sesuai dengan ukuran, maka bimbingan dan efektivitas penatar teknis sudah dianggap valid. Pembimbing merupakan proses perbantuan (Facilitating) untuk guru mendapatkan ke efektivan dalam tugas-tugas mereka masa yang akan dating melalui pengembangan, kebiasaan berpikir, bertindak, keterampilan, pengetahuan dan sikap yang sesuai. (Dahana and Bhatnagar, 1980:672).

Menurut pendapat tersebut bahwa guru memegang peranan penting untuk mendukung keberhasilan peningkatan mutu pendidikan melalui bimtek. Peningkatan mutu guru melalui pelatihan dan pembinaan sangat efektif. Peranan akan terwujud untuk mampu memecahkan masalah guru dalam upaya meningkatkan kompetensinya. Guru yang belum paham terhadap pemberlakuan Kurikulum 2013 perlu sering dilatih dan dibina untuk dapat mengembangkan dirinya secara mandiri dalam wadah Gugus dan KKG untuk imbas teman sejawat.

\section{Metodologi Penelitian}

Metode wawancara digunakan dalam penelitian untuk tujuan tertentu, agar mendapat keterangan atau pendirian secara lisan dari respondent, dengan bercakap-cakap atau bertatap muka langsung kepada orang yang diwawancarai itu (Koentjakraningrat, 1977:162). Wawancara sebagai metode dipergunakan untuk mendapatkan data-data, keterangan-keterangan, pendirian-pendirian mengenai pokok masalah supaya hasil yang didapatkan mencakup keseluruhan. Mengenai wawancara mendalam dilakukan terhadap informan tertentu, yakni wawancara kepada orang-orang yang dianggap tahu dan menguasai permasalahan yang sedang diteliti. Untuk mengarahkan pembicaraan pada pokok permasalahan dipergunakan pedoman wawancara.

Suatu pedoman wawancara, tentunya harus benar-benar dapat dimengerti oleh pengumpul data, sebab dialah yang akan menanyakan dan menjelaskan pada responden (Fasial, 2001:52). Penggunaan metode dalam Penelitian Tindakan ini bertujuan untuk meningkatkan, kinerja guru pendidikan Agama Hindu dalam menyusun silabus pembelajaran melalui bintek. Tindakan yang dilakukan adalah bintek penyusunan silabus, jenis penelitian tindakan yang dipilih adalah jenis emansipatori.Jenis ini dianggap paling tepat karena penelitian ini dilakukan untuk mengatasi permasalahan pada wilayah kerja peneliti sendiri berdasarkan pengalaman sehari-hari. Berdasarkan hasil observasi, repleksi diri, guru bersedia melakukan perubahan sehingga kinerjanya sebagai pendidik akan mengalami perubahan agar bisa lebih meningkat rancangan penelitian yang digunakan adalah model kemis yang terdiri dari atas empat langkah, yakni : perencanaan, pelaksanaan, observasi, dan refleksi (Wardhani,2007:45).

Indikator keberhasilan adalah dengan penskoran dalam menentukan ketuntasan minimal bimbingan teknis pembuatan silabus di Gugus 1 Kecamatan Kintamani sebagai berikut :

Jika mendapat nilai :

1. 85-100 katagori sangat baik predikat $\mathrm{A}$

2. 70-84 katagori baik predikat $B$

3. 55-69 katagori cukup predikat $\mathrm{C}$

4. 54 ke bawah katagori kurang predikat $\mathrm{D}$

Penelitian tindakan sekolah dinyatakan berhasil jika peserta mengalami peningkatan dan mendapat predikat minimal B atau katagori baik, dengan setiap tahapan siklus senantisa mengalami peningkatan. Berdasarkan pemahaman yang diberikan oleh narasumber dalam menyusun silabus sebagai bahan awal dalam mempersiapkan perangkat pembelajaran. pemahaman akan peraturan perundang-undangan yang terus berkembang pada Kurikulum 2013 menuntut guru harus aktif kreatif dan inovatif dalam mengembangkan kemapuan dirinya. 


\section{HASIL DAN PEMBAHASAN}

Gambaran hasil yang didapat berdasarkan rekaman fakta observasi dilapangan para guru pendidikan agama hindu sekolah dasar di gugus I Kintamani, kecamatan kintamani pada awalnya pemahaman terhadap penyusunan atau membuat silabus dianggap tidak terlalu penting penyusunan kurikulum atau silabus hanya persyaratan administrasi saja. Sehingga silabus yang dibuat tidak sesuai dengan karakteristik mata pelajaran.

Dengan demikian tampak jelas, kinerja guru agama hindu dalam menyusun silabus pembelajaran hanya saja didasari oleh contohcontoh yang ada tanpa menganalisis secara kritis berdasarkan standar yang telah ditetapkan sehingga kualitas pembelajaran jauh dari apa yang diharapkan. Hampir semua guru agama hindu ditemukan kurang paham tehadap sema aspek-aspek yang ada dalam memasukan kedalam silabus pembelajaran. Kelemahan umum yang tampak pada guru adalah sebagai berikut :

1. Guru agama hindu belum mampu menyusun silabus dengan baik.

2. Guru agama hindu belum mampu membuat indicator pencaian kompetensi berdasarkan kata kunci KD.

3. Guru agama hindu belum mampu memasukan atau menuangkan KKO kedalam inidkator pencaian kompetensi untuk menentukan bentuk silabus.

4. Semua guru agama hindu belum memahami tentang kurilkulum dan silabus pembelajaran K13.

5. Guru agama hindu belum mampu menyusun silabus buatan sendiri tetapi masih copy paste.

6. Guru agsma belum mampu memanage waktu, penilaian, dari awal sampai proses pembelajaran berakhir.

Dengan kondisi awal seperti ini perlu adanya pembinaan atau tindakan nyata yang diharapkan mampu meningkatkan kinerja guru agama dalam menyusun kurikulum atau silabus yaitu melalui bintek penyusunan silabus.
Hasil Penilaian Masing-Masing Siklus Berdasarkan analisis dan observasi seperti yang dipaparkan pada bagian sebelumnya, maka penelitian tindakan sekolah berhasik baik karena terjadi peningkatan aktifias guru dalam kegiatan menyusun silabus bagi guru pendidikan agama Hindu di Gugus I Kintamani, Kabupaten Bangli. Disamping itu juga terjadi peningakatan kinerja guru agama Hindu melalui bintek silabus gugus I, dari siklus I ke siklus II pada masing-masing aspek dengan target ketercapaian sesuai dengan kriteria yang ditetapkan minimal mendapat predikat baik. Melalui bintek menyusun silabus sangat efektif untuk meningkatkan kompetensi guru dalam merencanakan pembelajaran yang diawali dengan mempersiapkan perangkat pembelajaran berupa silabus.

Berdasarkan tindakan ini disebabkan karena pemahaman secara menyeluruh tentang perangkat pembelajaran sangat diperlukan. Dengan pemahaman yang baik, maka perangkat pembelajaran dapat disusun dengan baik. Mengoptimalkan pemahaman guru agama hindu terhadap silabus pembelajaran, melalui pembinaan intensif dalam bentuk penyelenggaraan bintek silabus merujuk pada metode kooperatif konsultatif dimana diharapkan para guru berdiskusi, bekerjasama dan berkonsultasi secara aktif.

Perolehan hasil berdasrkan tahapan siklus mengalami peningkatan pada bimtek menysusun silabus bagi Guru Agama Hindu di Gugus 1 Kecamatan Kintamani Kabupaten Bangli meningkat tajam dari siklus 1 masih terdapat predikat cukup sebanyak 28\% selanjutnya di siklus 2 manjadi tidak ada yang mendapat nilai cukup dan peningkatanya adalah sebagai berikut dari siklus 1 yang mendapat predikat sangat baik sebanyak $18 \%$ meningkat menjadi $55 \%$ terjadi peningkatan sangat tinggi yakni sebesar $37 \%$.

Dengan demikian pemahaman guru dalam menyususn silabus berdarakan permendikbud no 22 ytahun 2016 sudah baik sehingga dapat menyusun silabus sebagai awal perangkat 
pembelajaran yang selanjutnya akan dituangkan dalam bentuk RPP dan diimplementasikan dalam kelas saat proses pembelajaran.

\section{KESIMPULAN}

Berdasarkan analisis dan pembahasan yang dipaparkan pada bagian sebelumnya, maka dapat disimpulkan sebagai berikut :

Proses pelaksanaan penyusunan silabus melalui bintek atau bimbingan teknis untuk meningkatkan kinerja guru pendidikan agama hindu dalam menyusun perangkat pembelajaran sebagai langkah awal sebelum melaksanakan proses pembelajaran di dalam kelas.

Terjadi peningkatan kemampuan guru agama Hindu di Gugus I Kintamani Kintamani Kabupaten Bangli dari 11 guru awalnya digugus 1 masih ada yang mendapat predikat cukup sebesar $28 \%$ selanjutnya pada siklus 2 menjadi tidak ada mendapat predikat cukup dan mendapat predikat baik sebanyak $45 \%$ sehingga peningkatanya sebesar $17 \%$ dari cukup ke baik. Sedangkan siklus 1 mendapat predikat sangat baik sebanyak $18 \%$ disiklus 2 menjadi $55 \%$ sehingga mengalami peningkatan sebesar $37 \%$ pada bintek penyusunan silabus dari siklus I sampai dengan siklus II ditargetkan sesuai dengan yang ditargetkan sangat efektif dapat predikat baik dalam penyusunan silabus.

\section{SARAN}

1. Kepada para guru sebelum melakukan proses pembelajaran agar memperhatikan proporsi waktu, materi ajar, jangan mencontoh dengan silabus yang telah ada disesuaikan dengan perkembangan pendidikan dengan perkembangan jaman.

2. Pembinaan melalui bintek dapat berjalan secara efektif dan efisien agar semua guru aktif bekerja sama dengan rekan sejawat, kolaboratif, konsultatif.

3. Peningkatan kinerja guru dalam menyusun silabus pembelajaran akan berjalan dengan efektif bila semua kompenen mendukung memfasilitasi kegiatan tersebut secara rutin.

4. Pembinaan penyusunan silabus melalui bintek semoga dapat dijadikan salah satu alternative sebagai upaya dalam meningkatkan kompetensi guru dalam mengembangkan materi ajar pada proses pembelajaran.

\section{DAFTAR PUSTAKA}

Amalembun, 1987: Faktor- factor yang mempengaruhi Kualitas Proses Belajar Mengajar dan Implikasinya bagi Pengembangan Pendidikan yang Relevan. Analisis Pendidikan No.3 tahun 11

Nana Sudjana, 1998.Dasar- Dasar Proses Belajar Mengajar. Sinar Baru. Bandung.

Nurkancana dan PPN Sumartana,1983. Evaluasi pendidikan Penerbit Usaha nasional Surabaya Indonesia

$\begin{array}{cc}\text { Poerwanto, } & \text { 1989.Strategi } \\ \text { Mengajar.F.PIPS IKIP Malang }\end{array}$ Roeslan, 1986.Pendekatan dalam Proses Belajar Mengajar. CV. Remaja Resdokarya Bandung

Sardiman, A.M,1990, Interaksi dan Motivasi Belajar Mengajar Pedoman bagi Guru dan Calon Guru. Edisi I.cetakan ke 31 Rajawali, Jakarta.

Slameto,1996.Guru dan Proses Belajar Mengajar. Penerbit Sinar Baru Bandung Suharsini Ari Kunto, 1993.Prosedur Penelitian Suatu Pendekatan Praktik. Penerbit Rineka Cipta Jakarta

Sumaryono, 1991. Pengantar Umum Pendidikan, Aksara Baru. Jakarta. 